\title{
PENGARUH EDUKASI TERHADAP PENGETAHUAN MASYARAKAT TENTANG DETEKSI DINI ALZHEIMER DI KELURAHAN LABUH BARU PEKANBARU
}

\author{
Angga Arfina \\ Program Studi S1 Keperawatan, STIKes Payung Negeri Pekanbaru \\ Email: angga_arfina@yahoo.com
}

Diterima : November 2021, Diterbitkan : Desember 2021

\begin{abstract}
Abstrak
Penyakit alzheimer merupakan salah satu penyakit gangguan pada otak bersifat ireversibel yang menyebabkan gangguan memori, keterampilan berpikir dan perubahan perilaku. Deteksi dan diagnosis yang dilakukan lebih awal pada penyakit alzheimer akan memberikan manfaat yang membantu individu dan keluarga penderita. Edukasi berperan membantu masyarakat untuk meningkatkan pengetahuan tentang deteksi dini penyakit alzheimer. Penelitian ini bertujuan mengetahui pengaruh edukasi terhadap pengetahuan masyarakat tentang deteksi dini alzheimer di Kelurahan Labuh Baru Kota Pekanbaru. Penelitian ini merupakan penelitian deskriptif kuantitatif dengan desain quasi eksperiment pre and post test without control. Sampel penelitian adalah masyarakat yang berjumlah 30 orang dengan teknik consecutive sampling. Pengumpulan data dilakukan dengan kuesioner pengetahuan deteksi dini alzheimer. Data dianalisis menggunakan statistik uji $\mathrm{T}$ dependen. Hasil penelitian menunjukkan ada peningkatan pengetahuan deteksi dini alzheimer yaitu dari rata-rata 5.733 sebelum edukasi menjadi 6.633 sesudah diberikan edukasi. Hasil uji T diperoleh nilai mean 0.900 dengan standar deviasi 1.241 dan $\mathrm{p}$ value 0,000 artinya ada perbedaan yang signifikan pengetahuan masyarakat tentang deteksi dini alzheimer antara sebelum dan sesudah pemberian edukasi. Edukasi dapat meningkatkan pengetahuan masyarakat tentang deteksi dini dari penyakit alzheimer dan secara lebih efektif diharapkan mampu mencegah komplikasi yang dapat muncul.
\end{abstract}

Kata Kunci: Edukasi, Pengetahuan Deteksi Dini, Alzheimer

\begin{abstract}
Alzheimer's disease is an irreversible brain disorder that causes memory impairment, thinking skills, and behavioral changes. Early detection and diagnosis of Alzheimer's disease will provide benefits that help individuals and families of sufferers. Education plays a role in helping the community increase knowledge about early detection of Alzheimer's disease. This study aims to determine the effect of education on public knowledge about early detection of Alzheimer's in Labuh Baru Village, Pekanbaru City. This research is a quantitative descriptive study with a quasi-experimental pre and post-test design without control. The sample of this research is 30 people with consecutive sampling techniques. Data was collected using a knowledge questionnaire on Alzheimer's early detection. Data were analyzed using dependent T-test statistics. The results showed an increase in knowledge of early detection of Alzheimer's, from an average of 5.733 before education to 6.633 after being given education. The Ttest results obtained a mean value of 0.900 with a standard deviation of 1.241 and a p-value of 0.000 , meaning a significant difference in public knowledge about early detection of Alzheimer's between before and after giving education. Education can increase public knowledge about early detection of Alzheimer's disease and more effectively does expected to be able to prevent complications that can arise.
\end{abstract}

Keywords: Education, Knowledge of Early Detection, Alzheimer 


\section{PENDAHULUAN}

Penyakit alzheimer merupakan penyakit bersifat ireversibel yang mengenai otak secara bertahap dan perlahan menghancurkan memori dan keterampilan berpikir rasional untuk dapat melakukan tugas yang paling sederhana. Penyakit alzheimer yang paling sering adalah demensia yang ditandai dengan hilangnya fungsi kognitif, berpikir, mengingat, menalar dan kemampuan perilaku untuk melakukan aktivitas atau kegiatan dasar sehingga dapat mengganggu kehidupan sehari-hari seseorang. Sebagian besar kasus alzheimer terjadi setelah usia 60 tahun dan hampir 3\% kasus pada pria dan wanita terjadi pada usia 65 - 74 tahun (Alhumaidi et al., 2020).

Penderita alzheimer secara khas akan menunjukkan gejala gangguan memori dan kemampuan pengambilan keputusan serta masalah lainnya seperti perilaku dan kemampuan verbal mereka. Masalah lainnya yang dihadapi oleh penderita alzheimer antara lain jatuh, kehilangan martabat dan rasa hormat, pelecehan, penelantaran serta eksploitasi (Alhumaidi et al., 2020). Setiap tahun insiden alzheimer di seluruh dunia mengalami peningkatan dengan cepat. Alzheimer's Disease International melaporkan saat ini diperkirakan terdapat 46,8 atau 50 juta orang terdiagnosis alzheimer di dunia. Sementara kasus yang dilaporkan di Asia Pasifik terdapat 20,9 juta kasus (WHO, 2017).

Prevalensi alzheimer di Indonesia diperkirakan sekitar 1,2 juta pada tahun 2016 dan akan meningkat menjadi 2 juta tahun 2030 serta 4 juta pada tahun 2050 (WHO, 2017). Meningkatnya kasus alzheimer demensia ini dapat disebabkan oleh beberapa faktor antara lain kurangnya pemahaman atas penyakit, kurangnya sumber daya serta pelatihan bagi para pendamping orang dengan demensia alzheimer (WHO, 2017). Selain itu pengetahuan masyarakat tentang penyakit alzheimer juga masih kecil. Hal ini disebabkan sebagian besar masyarakat menganggap alzheimer merupakan penyakit akibat proses penuaan yang sifatnya alami (Yunita \& Ghofir, 2019).

Meningkatkan pengetahuan masyarakat tentang alzheimer membantu untuk mengatasi stigma dan memberikan informasi yang lebih baik tentang kebutuhan individu penderita dan keluarganya. Langkah pertama yang dapat dilakukan untuk meningkatkan pengetahuan masyarakat adalah dengan menilai pengetahuan masyarakat serta mengidentifikasi kesenjangan pengetahuan menggunakan alat penilaian yang andal. Peningkatan pengetahuan masyarakat juga penting untuk membantu pencegahan dan pengobatan pada alzheimer (Alhumaidi et al., 2020).

Penyakit alzheimer sampai saat ini belum ditemukan obatnya sehingga sangat penting untuk melakukan deteksi dini. Salah satu penyebab kurang optimalnya perawatan pada penyakit alzheimer adalah kurangnya pengetahuan atau keterampilan dalam mendiagnosis dan manajemen penyakit. Hal ini akan menyebabkan penundaan diagnosis sehingga pengobatan dan manajemen penyakit juga ikut tertunda (Nagle et al., 2013). Deteksi dan diagnosis yang dilakukan lebih awal pada penyakit alzheimer akan memberikan manfaat yang membantu individu dan keluarga penderita (Yunita \& Ghofir, 2019).

Salah satu upaya yang dapat dilakukan untuk mengurangi beban perawatan dan manajemen penyakit baik untuk pasien dan keluarga adalah dengan mengurangi ketidaktahuan tentang penyakit alzheimer (Nagle et al., 2013). Oleh sebab itu pengetahuan dalam mengelola penyakit sangat penting bagi seluruh masyarakat (Arifi, 2020). Tindakan yang dapat meningkatkan pengetahuan masyarakat adalah dengan melakukan promosi kesehatan dengan pendidikan kesehatan.

Pendidikan kesehatan (health education) merupakan kombinasi dari pengalaman belajar yang dirancang untuk mempengaruhi, mengaktifkan dan memperkuat perilaku secara sukarela yang kondusif bagi kesehatan baik individu, keluarga, kelompok atau komunitas sehingga mampu memfasilitasi proses yang memungkinkan untuk membuat keputusan dengan adanya informasi yang baik tentang praktik kesehatan. Pendidikan kesehatan merupakan bagian dari keseluruhan upaya kesehatan meliputi promotif, preventif dan rehabilitatif yang menitikberatkan pada upaya untuk meningkatkan perilaku hidup sehat. Tujuan dari pendidikan kesehatan ini adalah 
agar terjadi perubahan perilaku dari yang merugikan kesehatan atau tidak sesuai dengan norma kesehatan ke arah tingkah laku yang menguntungkan kesehatan (Pakpahan et al., 2021).

Studi pendahuluan yang dilakukan di Kelurahan Labuh Baru Kota Pekanbaru pada 5 orang masyarakat terdapat $60 \%$ masyarakat yang belum memahami tentang tanda dan gejala awal penyakit alzheimer dan menganggap alzheimer merupakan penyakit yang terjadi pada lansia. Hal ini memerlukan tindakan berupa pemberian informasi agar masyarakat lebih memahami tentang penyakit alzheimer. Peningkatan pengetahuan dapat menyebabkan perubahan perilaku yang berhubungan dengan kesehatan. Hal ini dapat menjadi dasar sebagai upaya untuk meningkatkan status kesehatan seseorang (Woo, 2017). Berdasarkan uraian tersebut maka peneliti tertarik untuk melakukan penelitian tentang "Pengaruh Edukasi Terhadap Pengetahuan Masyarakat Tentang Deteksi Dini Alzheimer di Kelurahan Labuh Baru Pekanbaru."

\section{METODE PENELITIAN}

Penelitian ini merupakan penelitian kuantitatif dengan desain yang digunakan adalah "Quasy Experimental pre and post test without control group. Dalam penelitian ini, terdapat satu grup yang kemudian diberi pretest untuk mengetahui pengetahuan awal responden. Setelah itu responden diberikan perlakuan berupa memberikan edukasi tentang pencegahan penyakit alzheimer. Setelah diberikan intervensi kemudian dilakukan post test pada grup untuk membandingkan perbedaan sebelum dan setelah diberikan intervensi.

Penelitian ini dilakukan di Kelurahan Labuh Baru kota Pekanbaru. Peneliti menetapkan jumlah sampel dalam penelitian ini adalah 30 orang dengan metode non probability sampling. Teknik pengambilan sampel dilakukan secara consecutive sampling dengan kriteri inklusi masyarakat yang berisiko alzheimer, kooperatif dalam kegiatan edukasi.

Pengumpulan data dilakukan dengan lembar kuesioner tentang pengetahuan masyarakat dalam deteksi dini alzheimer. Instrumen ini merupakan kuesioner yang diadopsi dari tes deteksi alzheimer yang dikembangkan oleh Banner Sun Health Research Institute yang telah dilakukan uji validitas dan reliabilitas pada 30 orang responden di Kelurahan Labuh Baru pada bulan Januari 2020. Hasil uji validitas kuesioner didapatkan dengan membandingkan nilai $r$ tabel dan nilai $r$ hitung pada setiap item pertanyaan pada tingkat kemaknaan 5\% ( $\mathrm{df}=\mathrm{n}-2)$. Hasil yang didapat dari 9 item pertanyaan dinyatakan valid dengan $r$ hitung $\geq 0.3610$. Uji reliabilitas kuesioner dilihat dari nilai Cronbach Alpha dengan nilai $\geq 0.6$ dinyatakan reliabel. Hasil perhitungan didapatkan nilai Cronbach Alpha 0.731, maka semua pertanyaan dalam kuesioner dinyatakan reliabel. Setiap jawaban ya diberi nilai 1 sedangkan jawaban tidak diberi nilai 0 . Data dianalisis secara statistik deskriptif dan uji $\mathrm{T}$ dependen.

\section{HASIL PENELITIAN DAN PEMBAHASAN}

Hasil analisis dalam penelitian ini terdiri dari analiasis univariat dan analisis bivariat. Penelitian telah dilakukan di Kelurahan Labuh Baru kota Pekanbaru. Penelitian dilakukan pada bulan Januari 2020 dengan subjek penelitian masyarakat yang sesuai dengan kriteria inklusi berjumlah 30 orang responden.

Hasil analisis univariat karakteristik responden dapat dilihat pada tabel sebagai berikut:

\section{Tabel 1}

Distribusi Karakteristik RespondenBerdasarkan Usia, Jenis Kelamin, Pendidikan dan Pekerjaan di Kelurahan Labuh Baru Pekanbaru $(n=30)$

\begin{tabular}{llcc}
\hline No & \multicolumn{1}{c}{$\begin{array}{c}\text { Karakteristik } \\
\text { Responden }\end{array}$} & Jumlah & Persenatase \\
\hline 1 & Usia & & \\
& $26-35$ (Dewasa awal) & 5 & 16.7 \\
& $36-45$ (Dewasa akhir) & 8 & 26.7 \\
& $46-55$ (Lansia awal) & 8 & 26.7 \\
& $56-65$ (Lansia akhir) & 9 & 30.0 \\
&
\end{tabular}




\begin{tabular}{llcc}
\hline 2 & Jenis Kelamin & & \\
& Laki-laki & 20 & 66.7 \\
& Perempuan & 10 & 33.3 \\
\hline 3 & Pendidikan & & \\
& SD & 10 & 33.3 \\
& SMA & 14 & 46.7 \\
& Pergiruan Tinggi & 6 & 20.0 \\
\hline 4 & Pekerjaan & & \\
& Tidak bekerja/Pensiun & 21 & 70.0 \\
& Buruh & 1 & 3.3 \\
& Swasta & 5 & 16.7 \\
& Wiraswasta & 1 & 3.3 \\
& PNS/TNI/POLRI & 2 & 6.7 \\
\hline
\end{tabular}

Tabel 1. menunjukkan karakteristik responden paling banyak berusia antara $56-65$ tahun yaitu 9 orang $(30.0 \%)$. Jenis kelamin mayoritas responden adalah laki-laki yaitu 20 orang $(66.7 \%)$ dan sebagian besar responden mempunyai tingkat pendidikan SMA sebanyak 14 orang $(46,7 \%)$. Responden rata-rata tidak bekerja atau sudah pensiun yaitu sebanyak 21 orang $(70.0 \%)$.

Penyakit alzheimer ditandai dengan gangguan neurodegeneratif yang muncul pada usia kurang dari 65 tahun (Mendez, 2019). Pada penelitian ini $30.0 \%$ responden berusia $56-65$ tahun yang termasuk dalam kategori lansia akhir. Hal ini memungkinkan responden untuk berisiko terkena alzheimer. Berdasarkan riwayat penyakit alzheimer lebih berisiko terjadi pada wanita dibandingkan pria. Sekitar dua per tiga orang yang terdiagnosis alzheimer adalah wanita. Namun beberapa penelitian yang dilakukan di Amerika melaporkan bahwa kejadian alzheimer berdasarkan jenis kelamin pada usia lebih dari 80 tahun tidak menunjukkan perbedaan. Hasil penelitian ini menunjukkan bahwa jenis kelamin laki-laki lebih banyak dari pada perempuan yaitu $66.7 \%$. Hal ini memungkinkan baik laki-laki maupun perempuan yang menjadi responden penelitian mempunyai risiko yang sama untuk terkena alzheimer. Penelitian lain menyatakan bahwa tidak ada perbedaan jenis kelamin terhadap risiko untuk terjadinya alzheimer (Mielke, 2018).

Tingkat pendidikan merupakan faktor predisposisi terjadinya demensia. Tingkat pendidikan berhubungan dengan kemampuan dan aktivitas belajar dari seseorang. Belajar mampu menjaga ketajaman daya ingat dan senantiasa mengoptimalkan fungsi otak. Pendidikan mampu mengkompensasi neurodegeneratif dan ganggaun vaskular yang mempengaruhi otak. Individu yang mempunyai pendidikan yang lebih lanjut memiliki berat otak yang lebih mampu menghadapi berbagai masalah kognitif. Penelitian ini sebagian besar responden mempunyai tingkat pendidikan SMA yaitu sebanyak $46.7 \%$ yang berisiko terjadinya alzheimer. Hal ini didukung oleh penelitian yang dilakukan di Panti Wherda Bina Bhakti Tangerang Selatan yang menyatakan ada hubungan tingkat pendidikan dengan kejadian demensia p value 0.007 (Fatimah \& Lubis, 2018).

Aktivitas fisik mempunyai pengaruh yang bermanfaat pada fungsi kognitif seseorang. Saat berusia lanjut aktivitas fisik mampu mencegah gangguan fungsi kognitif dan timbulnya demensia. Hasil penelitian Fatimah dan Lubis (2018), menyatakan ada hubungan aktivitas fisik dengan kejadian demensia pada lansia di Panti Wherda Bina Bhakti Tangerang Selatan dengan $\mathrm{p}$ value 0.015. namun berdasarkan penelitian ini sebanyak $70.0 \%$ responden sudah tidak bekerja atau pensiun. Hal ini menyebabkan responden kurang melakukan aktivitas fisik dan berdampak terhadap risiko untuk terjadinya alzheimer.

Analisis bivariat dilakukan untuk mengetahui pengaruh variabel independen yaitu edukasi alzheimer terhadap variabel dependen yaitu pengetahuan masyarakat tentang deteksi dini alzheimer. Analisis dilakukan dengan menggunakan uji $\mathrm{T}$ dependen dengan hasil sebagai berikut:

Tabel 2

Perbedaan Pengetahuan Masyarakat Tentang Deteksi Dini Alzheimer Sebelum dan Sesudah Diberikan Edukasi di Kelurahan Labuh Baru Kota Pekanbaru

\begin{tabular}{llcc}
\hline Pengetahuan & Mean & SD & p value \\
\hline Sebelum & 5.733 & 2.391 & \multirow{2}{*}{0.000} \\
\cline { 1 - 3 } Sesudah & 6.633 & 1.809 & \\
\hline
\end{tabular}

Tabel 2. menunjukkan hasil uji statistik pengaruh edukasi alzheimer terhadap pengetahuan masyarakat tentang deteksi dini alzheimer. Hasil penelitian menyatakan bahwa pemberian edukasi meningkatkan perilaku 
responden dalam pengetahuan deteksi dini alzheimer yaitu dari rata-rata 5.733 sebelum edukasi menjadi 6.633 sesudah diberikan edukasi. Hasil uji T diperoleh nilai mean 0.900 dengan standar deviasi 1.241 dan p value 0.000 artinya secara statistik ada perbedaan yang signifikan pengetahuan masyarakat tentang deteksi dini alzheimer antara sebelum dan sesudah pemberian edukasi.

Penyakit alzheimer merupakan penyakit yang ditandai dengan kerusakan sel saraf yang berhubungan dengan proses belajar dan memori, kemudia berkembang ke bagian yang mempengaruhi pemikiran, penilaian dan perilaku individu yang terkena. Peran dari orang yang memberikan perawatan pada penderita alzheimer sangat penting. Hal ini berkaitan dengan pengetahuan tentang gejala, perawatan dan perkembangan penyakit, jadwal pengobatan, rehabilitasi serta pemberian dukungan (Sharma \& Kaur, 2016). Pengetahun yang kurang baik tentang alzheimer mengakibatkan kurangnya pemanfaatan layanan kesehatan dan pengobatan, penundaan dalam diagnosa sehingga akan memperpanjang inisiasi perawatan dan komplikasi lainnya (Smith et al., 2014).

Mengatasi defisit pengetahuan merupakan salah satu kunci untuk meningkatkan perawatan dan kesehatan pada penderita alzheimer di masa yang akan datang (Smith et al., 2014). Hal ini di dukung oleh penelitian yang dilakukan di daerah pedesaan Amerika dengan memberikan edukasi kepada masyarakat yang berisiko alzheimer berusia 50 tahun ke atas. Edukasi diberikan setiap satu kali seminggu sekama 90 menit per sesi. Hasil penelitian ini menyatakan ada peningkatan pengetahuan tentang alzheimer setelah diberikan edukasi dengan $\mathrm{p}$ value $=0.03$ (Blocker et al., 2020). Penelitian lain yang dilakukan pada 30 orang kader posyandu lansia di Kelurahan Mersi Kecamatan Purwokerto Timur terdapat perbedaan nilai rata-rata pengetahuan sebelum dan sesudah diberikan edukasi tentang alzheimer. Hasil penelitian ini menunjukkan rata-rata pengetahuan sebelum edukasi adalah 53.00 dan sesudah edukasi 80.67 dengan hasil uji statistik paired T test didapatkan $\mathrm{p}$ value $=0.000$ (Taufik \& Isworo, 2021) .
Pengetahuan merupakan hasil dari tahu yang terjadi setelah melakukan penginderaan melalui indra penglihatan, pendengaran, penciuman, rasa dan raba terhadap suatu objek tertentu. Tanpa pengetahuan seseorang tidak mempunyai dasar untuk mengambil keputusan dan menentukan tindakan terhadap masalah yang dihadapi. Salah satu upaya yang dapat dilakukan untuk meningkatkan pengetahuan adalah dengan adanya sumber informasi yang bisa didapatkan dari pendidikan kesehatan. Pendidikan kesehatan mempunyai beberapa tujuan antara lain tercapainya perubahan perilaku baik individu, keluarga dan masyarakat dalam membina dan memelihara perilaku sehat dan lingkungan sehat serta peran aktif dalam upaya mewujudkan derajat kesehatan yang optimal. Selain itu dapat terbentuknya perilaku sehat pada individu, keluarga dan mental maupun sosial sehingga dapat menurunkan angka kesakitan dan kematian (Pakpahan dkk, 2021).

\section{SIMPULAN}

Hasil penelitian menyatakan bahwa pemberian edukasi meningkatkan perilaku responden dalam pengetahuan deteksi dini alzheimer yaitu dari rata-rata 5.733 sebelum edukasi menjadi 6.633 sesudah diberikan edukasi. Hasil uji T diperoleh nilai mean 0.900 dengan standar deviasi 1.241 dan $\mathrm{p}$ value 0.000 artinya secara statistik ada perbedaan yang signifikan pengetahuan masyarakat tentang deteksi dini alzheimer antara sebelum dan sesudah pemberian edukasi. Deteksi dini alzheimer sangat mendukung untuk mencegah tejadinya perluasan dan beratnya gejala yang dialami oleh pasien. Edukasi dapat meningkatkan pengetahuan masyarakat tentang deteksi dini dari penyakit alzheimer dan secara lebih efektif diharapkan mampu mencegah komplikasi yang dapat muncul.

\section{UCAPAN TERIMAKASIH}

Peneliti mengucapkan terimakasih kepada LPPM STIKes Payung Negeri Pekanbaru yang telah mendukung rangkaian penelitian ini, Ketua STIKes Payung Negeri Pekanbaru, Ketua 
RT Kelurahan Labuh Baru Kota Pekanbaru, mahasiswa yang membantu penelitian serta masyarakat yang telah berpartisipasi dalam pelaksanaan penelitian ini.

\section{DAFTAR PUSTAKA}

Alhumaidi, F. S., Siddiqui, M. I., Altowairqi, A. F., Alshawkani, H. H., Babkour, B. O., \& Alaugla, F. K. (2020). Public knowledge about Alzheimer disease in Mecca Region, Kingdom of Saudi Arabia: a cross-sectional study. https://doi.org/10.1186/s41983-020-00220-0

Arifi, M. N. Al. (2020). Evaluation of knowledge of Alzheimer disease among health university students in Riyadh, Saudi Arabia. Saudi Pharmaceutical Journal, 28(8), 911-915. https://doi.org/10.1016/j.jsps.2020.06.011.

Blocker, E. M., Fry, A. C., Luebbers, P. E., Burns, J. M., Perales-puchalt, J., Hansen,., \& D. M., Vidoni, E. D., (2020). Promoting Alzheimer's risk-reduction through Community-Based Lifestyle Education and Exercise in Rural America : 179-185. https://www.ncbi.nlm.nih.gov/pmc/articles/P MC7363174/.

Fatimah, S., \& Lubis, V. H. (2018). Hubungan Antara Tingkat Pendidikan, Aktivitas Fisik, Aktivitas Kognitif Dengan Kejadian Demensia Pada Lansia Mandiri Di Panti Wherda Bina Bhakti Tangerang Selatan Tahun 2018. Jurnal Kesehatan STIKes IMC Bintaro, II, 174-183. http://jurnal.stikesimcbintaro.ac.id/index.php/ djs/article/view/55.

Mendez, M. F. (2019). Early-onset Alzheimer disease and its variants. Continuum Lifelong Learning in Neurology, 25(1), 34-51. https://doi.org/10.1212/CON.0000000000000 687

Mielke, M. M. (2018). Sex and gender differences in Alzheimer disease dementia. Psychiatric Times, 35(11), 14-15. https://www.ncbi.nlm.nih.gov/pmc/articles/P MC6390276/

Nagle, B. J., Usita, P. M., \& Edland, S. D. (2013). United States medical students' knowledge of Alzheimer disease. Journal of Educational Evaluation for Health Professions, 10, 4. https://doi.org/10.3352/jeehp.2013.10.4
Pakpahan, M et al. (2021). Promosi kesehatan \& perilaku kesehatan. Jakarta: Yayasan Kita Menulis.

Sharma, P., \& Kaur, M. (2016). A study to assesss the effect of structured teaching programe on knowledge regarding alzheimer's disease among adults. https://doi.org/10.5958/23208651.2016.00001.6.

Smith, B. J., Ali, S., \& Quach, H. (2014). Public knowledge and beliefs about dementia risk reduction : a national survey of Australians. 110. https://doi.org/10.1186/1471-2458-14-661. https://doi.org/10.1186/1471-2458-14-661.

Taufik, A., \& Isworo, A. (2021). Upaya peningkatakan kualitas hidup lansia melalui gerakan enam pilar menuju masyarakat bebas demensia, Kelurahan Mersi Kecamatan Purwokerto Timur. 2(2), 32-42. http://jos.unsoed.ac.id/index.php/jchd/article/v iew/3629.

WHO. (2017). Statistik tentang demensia. Diakses dari https://alzi.or.id/statistik-tentangdemensia/.

Woo, B. K. (2017). Dementia Health Promotion for Chinese Americans. 9(6). https://doi.org/10.7759/cureus.1411.

Yunita, U. E., \& Ghofir, A. (2019). Uji validitas dan reliabilitas alzheimer disease assesment scalecognitive modifikasi Indonesia (ADAS-COG Ina) untuk skrining awal penyakit alzheimer. http://etd.repository.ugm.ac.id/penelitian/detai $1 / 182223$. 